\title{
Toxic risks from inhalation of bacterial endotoxin
}

\author{
Robert Burrell, Shu-Hua Ye
}

\begin{abstract}
A potential risk for workers exposed to inhalation of endotoxin, as well as the primary tissue changes, is the possibility of subsequent development of adult respiratory distress syndrome. Accordingly, hamsters were administered one hour aerosols of Enterobacter agglomerans and allowed to rest for six hours to produce maximum microlesions in the lung. One hour before this peak, the animals were injected intravascularly with the same suspension used in the aerosol. After one hour the animals were killed and bronchopulmonary lavages were made for analysis of free lung cells. As anaesthesia alone has been reported to be one of the operative procedures that enhance the effect of previous exposure to endotoxin, controls had to include sham anaesthesia with no intravascular injection. Endotoxin inhalation induced significant increases in total number of pulmonary leucocytes, mostly neutrophils, but with a concomitant relative decrease in number of alveolar macrophages. These polymorphonuclear neutrophils are not seen in morphometric analysis of the alveoli. Of greater interest was the large increase in erythrocytes suggesting pulmonary haemorrhages. Such changes were not due to intravenous bacteria alone, and were only significant when the bacteria were inhaled. Taken together with the other known inflammatory effects of inhaled bacteria or bacteria containing endotoxin, such inhalation in an occupational setting constitutes an increasingly recognised risk for workers.
\end{abstract}

The effect of bacterial endotoxin on the lung is an important factor in shock following sepsis and adult respiratory distress syndrome (ARDS) wherein endotoxin or mediators stimulated by this ubiquitous

\footnotetext{
Department of Microbiology and Immunology, West Virginia University Health Sciences Center, Morgantown, WV 26506, USA

R Burrell

Institute of Radiation Medicine, Shanghai Medical University, People's Republic of China

$\mathrm{S}-\mathrm{H}$ Ye
}

substance reach the lung through the peripheral circulation. Endotoxin is also important in causing pathophysiology to the lung when inhaled and thus represents a potential risk to workers subjected to certain types of environmental exposure.

It is known that inhalation of environmentally realistic concentrations of endotoxin $\left(4 \mu \mathrm{g} / \mathrm{m}^{3}\right.$ used experimentally compared with a reported naturally occurring range of $50 \mathrm{ng}-9 \mu \mathrm{g} / \mathrm{m}^{312}$ ) such as might be found in poultry processing plants or cotton mill carding rooms causes a number of reactions, depending on dose, within four to six hours. Among these are fever, ${ }^{3}$ neutropenia followed by leucocytosis, ${ }^{4}$ a decline in forced expiratory volume in one second $\left(\mathrm{FEV}_{1}\right),{ }^{3}$ endotoxin tolerance on subsequent challenge, ${ }^{56}$ increased production of leucocytic enzymes in bronchial alveolar lavages, ${ }^{7}$ pronounced decreases in lung volume due to changes in volume of the distal air space,${ }^{6}$ increased volume densities of neutrophils and platelets in pulmonary septal capillaries, ${ }^{6}$ appreciable changes in pulmonary capillary endothelium-for example, increased density of pinocytotic vesicles, cytoplasmic blebbing and focal disruption, ${ }^{6}$ increased pulmonary capillary permeability, ${ }^{8}$ and possible septal infiltration of fluids and inflammatory cells. ${ }^{8}$

Also, there is evidence that previous insults to the lung render the organ subsequently more vulnerable to exposure to endotoxin. Such predisposing factors could be surgical manipulation, intubation, anaesthesia, ${ }^{9}$ hypoxia, ${ }^{10}{ }^{11}$ burns, ${ }^{12}$ other effects induced by the endotoxin, ${ }^{12}$ or even recent exposure to endotoxin. ${ }^{5}$ To supplement the knowledge of the known risks to workers of inhaling endotoxin, the purpose of this study was to determine, in an experimental model of ARDS, if endotoxin inhalation may predispose workers to further pulmonary injury.

Materials and methods

Young adult male hamsters, an experimental species free of common pulmonary epizootics, were used throughout. Randomly divided groups of four or five animals each were administered either standardised aerosols of purified Enterobacter agglomerans lipopolysaccharide (LPS) as the source of endotoxin (five hours at $4 \mu \mathrm{g} / \mathrm{m}^{3}$ ) or saline suspensions of $E$ agglomerans cells (adjusted to an optical density ${ }_{540}$ of 0.400 ) for one hour. Control animals were unexposed.

At appropriate times after the cessation of the 
aerosol, the animals were anaesthetised with barbiturates and subjected to bronchoalveolar lavage. Cells from lavages were tested for viability by tryptan blue exclusion, counted, and analysed differentially by cytocentrifugation and Wright-Giemsa staining. All cells retained viability greater than $95 \%$.

\section{Results}

\section{EFFECT OF ENDOTOXIN INHALATION ON FREE LUNG}

CELLS

Twenty two hamsters were randomly divided into control, six, 24, and 48 hours post inhalation groups and subjected either to no aerosol (control) or the standard LPS inhalation challenge. Figure 1 gives results from the lavages taken at the designated times. These were statistically analysed by the two tailed $t$ test for independent variables ( $p$ was set at $<0.01$ ).

Inhaled endotoxin caused a clear increase in numbers of total free lung cells recovered by lavage, reaching a maximum at 24 hours and returning to near normal by 48 hours. Polymorphonuclear neutrophils began to increase proportionately within hours, reaching a maximum at six hours whereas alveolar macrophages reached their maximum number later, at 24 hours, and declined slowly after that time. Although the total cell count had returned to near normal 48 hours after aerosol exposure, the ratios of neutrophils and macrophages had not yet completely returned to normal values. Lymphocytes on the whole were unaffected except for a slight (nonsignificant) rise at 24 hours.

\section{COMPARISON OF INHALED ENDOTOXIN WITH INHALED} WHOLE BACTERIA

Pulmonary reactions were compared between animals challenged with saline suspensions of endo-

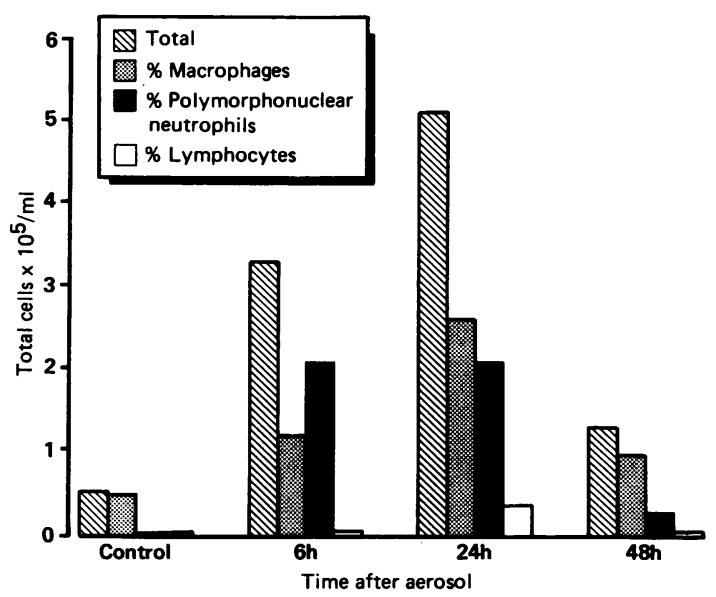

Figure 1 Free lung cell analysis of hamster bronchoalveolar lavages compared with time taken after inhalation.

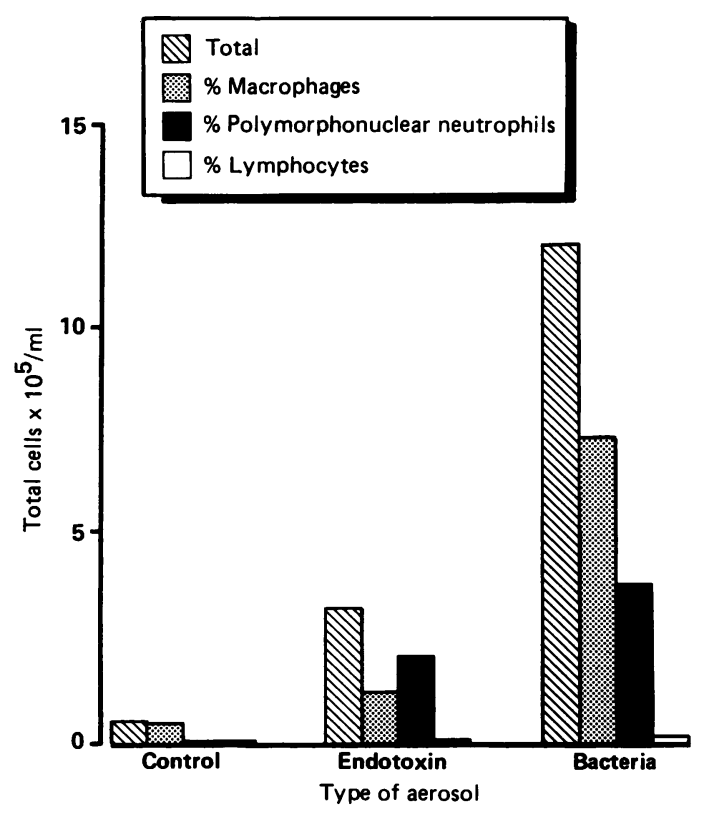

Figure 2 Comparison of free lung cell lavages taken six hours after inhalation of endotoxin or whole Gram negative bacteria.

toxin in an aerosol and animals given whole $E$ agglomerans for one hour. Lavages were made at only one time point, six hours, which was the time for development of maximum microlesions. ${ }^{4}$ Figure 2 gives the results statistically analysed as previously.

Inhalation of bacteria induced a significantly greater infiltration of leucocytes into the lung. Most of this infiltrate consisted of alveolar macrophages and neutrophils. The ratio of alveolar macrophages to neutrophils was greater in the animals receiving whole bacterial cells, whereas the ratio of neutrophils was higher in the endotoxin exposed animals.

\section{EFFECT OF COMBINED INHALATION AND}

INTRAVASCULAR CONTACT WITH WHOLE BACTERIA

Hamsters were given a standard aerosol of whole $E$ agglomerans cells for 30 minutes and allowed to rest for six hours to maximally develop pulmonary microlesions. ${ }^{6}$ One hour before this peak, the animals were anaesthetised and injected intravascularly with $0.2 \mathrm{ml}$ of the same suspension used for the aerosol. After one hour the animals were killed and bronchoalveolar lavages were made for free lung cell analyses. Because anaesthesia has been reported to be one of the operative procedures that may predispose the ARDS condition, controls included animals subjected to anaesthesia with no intravascular injection. Table 1 shows the data. Two types of comparisons were statistically analysed. Firstly, all treatment groups were compared with unexposed (normal) controls. Secondly, the complete regimen (aerosol, 
Table 1 Effect of combined pulmonary and intravascular exposure to bacterial endotoxin on free lung cells

\begin{tabular}{|c|c|c|c|c|c|c|c|c|}
\hline \multirow[b]{2}{*}{ Treatment } & \multicolumn{4}{|c|}{ Cells $\times 10^{5} / \mathrm{ml}(S D)$} & \multicolumn{4}{|c|}{$\%$ Cell content (SD) } \\
\hline & No & Total & $W B C$ & $R B C$ & $R B C$ & $M$ & $P M N$ & Ly \\
\hline \multirow{5}{*}{$\begin{array}{l}\text { Normal } \\
\text { Complete } \\
\text { Bacteria aerosol and } \\
\text { anaesthesia } \\
\text { Bacteria aerosol only } \\
\text { Anaesthesia and } \\
\text { intravascular bacteria }\end{array}$} & 10 & $0 \cdot 6(0 \cdot 1)$ & $0.5(0 \cdot 1)$ & $0.1(0.1)$ & $7 \cdot 7(9 \cdot 3)$ & $87 \cdot 0(9 \cdot 6)$ & $4 \cdot 5(4 \cdot 3)$ & $2 \cdot 6(1 \cdot 2)$ \\
\hline & 5 & $8.5(3.5)$ & $1.8(0.6)$ & $6 \cdot 7(3.5)$ & $31 \cdot 4(9 \cdot 6)$ & $36.0(9.9)$ & $31 \cdot 7(8 \cdot 1)$ & $0.3(0.3)$ \\
\hline & 8 & $6.8(1.0)$ & $2.5(1.1)$ & $3.2(1 \cdot 7) \dagger$ & $2.6(0.8) \dagger$ & $92 \cdot 0(2 \cdot 6) \dagger$ & $3.5(2.3)$ & $2 \cdot 0(1 \cdot 2)$ \\
\hline & 11 & $12 \cdot 1(6 \cdot 2)$ & $5 \cdot 1(4 \cdot 0)$ & $7.9(3.3) \ddagger$ & $2 \cdot 3(1.6) \ddagger$ & $61 \cdot 2(9 \cdot 8) \ddagger$ & $32.9(8.9)$ & $1 \cdot 2(1 \cdot 1)$ \\
\hline & 5 & $0.7(0.2)$ & $0.5(0.1)$ & $0.3(0.2)$ & $8 \cdot 8(6 \cdot 7)$ & $84.5(5 \cdot 4)$ & $2.9(1.8)$ & $3.7(1.8)$ \\
\hline
\end{tabular}

*Complete $=$ bacterial aerosol, anaesthesia, and intravenous bacteria groups.

$t_{n}=4 . \neq n=6$.

WBC = White blood cells; $\mathrm{RBC}=$ red blood cells; $\mathrm{M}=$ macrophages; $\mathrm{PMN}=$ polymorphonuclear neutrophils; Ly $=$ lymphocytes.

Table 2 Statistical analyses ( $p$ values) of bronchopulmonary lavage data shown in table 1

\begin{tabular}{|c|c|c|c|c|c|c|c|}
\hline & \multicolumn{3}{|c|}{ Cells $\times 10^{5}$} & \multicolumn{4}{|c|}{$\%$ Cell count } \\
\hline & Total & $W B C$ & $R B C$ & $R B C$ & $M$ & $P M N$ & $L y$ \\
\hline \multirow{4}{*}{$\begin{array}{l}\text { Complete } v \text { normal } \\
\text { Bacteria aerosol, and } \\
\text { anaesthesia } v \text { normal } \\
\text { Bacteria aerosol only } \\
v \text { normal } \\
\text { Anaesthesia and intravascular } \\
\text { bacteria } v \text { normal }\end{array}$} & 0.007 & 0.009 & 0.014 & 0.0005 & $<0.0001$ & $<0.0001$ & $<0.0001$ \\
\hline & $<0.0001$ & 0.001 & 0.04 & NS & NS & NS & NS \\
\hline & 0.0001 & 0.003 & 0.002 & NS & $<0.0001$ & $<0.0001$ & 0.01 \\
\hline & NS & NS & NS & NS & NS & NS & NS \\
\hline \multirow{2}{*}{$\begin{array}{l}\text { Bacteria aerosol and anaesthesia } \\
v \text { complete } \\
\text { Bacteria aerosol only } v \text { complete } \\
\text { Anaesthesia and intravascular } \\
\text { bacteria } v \text { complete }\end{array}$} & $\begin{array}{l}\text { NS } \\
\text { NS }\end{array}$ & $\begin{array}{l}\text { NS } \\
0.04\end{array}$ & $\begin{array}{l}\text { NS } \\
\text { NS }\end{array}$ & $\begin{array}{l}0.003 \\
0.003\end{array}$ & $\begin{array}{l}0.002 \\
0.0003\end{array}$ & $\begin{array}{l}0.002 \\
\text { NS }\end{array}$ & $\begin{array}{l}0.006 \\
0.04\end{array}$ \\
\hline & 0.008 & 0.01 & 0.015 & 0.003 & $<0.0001$ & 0.002 & 0.02 \\
\hline $\begin{array}{l}\text { Bacteria aerosol only } v \text { bacteria } \\
\text { aerosol and anaesthesia }\end{array}$ & 0.03 & NS & 0.03 & NS & $<0.0001$ & $<0.0001$ & 0.003 \\
\hline
\end{tabular}

See table 1 for details.

anaesthesia, and intravascular bacteria groups) was compared with each of the other groups. Table 2 gives the results.

Exposure to the complete regimen was characterised by a marked increase in number of erythrocytes and a relative decrease in the proportion of alveolar macrophages, whereas the neutrophils proportionately increased. This could indicate pulmonary haemorrhage. The anaesthetic, if anything, lessened the effects of the bacterial aerosol, and contributed little on its own to the free lung cell reaction. The combined anaesthetic and intravascular bacteria treatment had no significant effect.

\section{Discussion}

Inhalation of either purified bacterial endotoxin or whole cells induced significant increases in total number of pulmonary leucocytes, owing mostly to increases in alveolar macrophages and neutrophils. Inhalation of bacteria produced more pronounced reactions, with a greater neutrophil response, whereas the reaction to inhaled endotoxin was lower and predominantly due to alveolar macrophages. As these polymorphonuclear neutrophils are not seen in morphometric analysis of the alveoli, infiltration of the higher airways must be considered important.

If the lungs were to receive a second insult during the time when the inflammatory response to the initial stimulus was highest, the lung might be in a more vulnerable position. When inhalation of Gram negative bacteria was followed by an intravascular injection of similar cells, a large increase in number of erythrocytes, suggesting pulmonary haemorrhage, was accompanied by a relative decrease in the proportion of alveolar macrophages and a proportionate increase in neutrophils. Such changes were not due to intravenous bacteria alone, as they were only significant when the bacteria were inhaled.

Previous work with such a two staged pulmonary insult model was described using rabbits that were initially subjected to a bacterial aerosol and a subsequent intravascular administration 24 hours later. In this species, one in which the effects of platelet activating factor seem to be more severe, the animals responded by drastic prostaglandin dependent reductions in arterial $\mathrm{PaO}_{2}$ and peripheral platelet counts, and succumbed within hours to extensive interstitial pneumonitis and pulmonary haemorrhage. ${ }^{5}$ 
Taken together with the other known inflammatory effects of inhaled bacteria or bacteria containing endotoxin, such inhalation in an occupational setting constitutes an increasingly recognised risk for workers exposed to inhalation of Gram negative bacteria or their endotoxic components. Although a single exposure to endotoxin does not result in long lasting changes, the workers could still be at a health risk if continually exposed to endotoxin inhalation or if a single exposure happened to be coupled to an additional pulmonary insult. Workers exposed to such conditions and who may coincidentally be secondarily exposed within a definite period to other known risk factors may be at increased risk for developing ARDS. Additional risk factors seem to be necessary for inflammatory or physiological reactions to occur subsequently. Such factors could be surgical manipulation, intubation, anaesthesia, ${ }^{9}$ hypoxia, ${ }^{1011}$ burns, ${ }^{12}$ or even recent exposure to endotoxin. ${ }^{5}$ In each of these instances, the combined effects of endotoxin sensitisation might subsequently be enhanced if the endotoxin exposed worker was later coincidentally exposed to such an event promoting additional injury.

This study was supported in part by contract 82-521 from Cotton Inc, Raleigh NC.
1 Cavagna G, Foa V, Vigliani EC. Effects in man and rabbits of inhalation of cotton dust or extracts and purified endotoxins. Br J Ind Med 1969;26:314-21.

2 Olenchock SA, Lenhart SW, Mull JC. Occupational exposure to airborne endotoxins during poultry processing. $J$ Toxicol Environ Health 1982;9:339-49.

3 Pernis B, Vigliani EC, Cavagna C, Finulli M. The role of bacterial endotoxins in occupational disease caused by inhaling dusts. $\mathrm{Br} J$ Ind $\mathrm{Med}$ 1961;18:120-9.

4 Birch K. The role of endotoxin tolerance in byssinosis. Morgantown, WV: West Virginia University, 1983 (thesis).

5 DeMaria TF, Burrell R. Effects of inhaled endotoxin-containing bacteria. Environ Res 1980;23:87-97.

6 Lantz RC, Birch K, Hinton DE, Burrell R. Morphometric changes in the lung induced by inhaled bacterial endotoxin. Exp Mol Pathol 1985;43:305-20.

7 Burrell R, Rylander R. Further studies on inhaled endotoxincontaining bacteria. Environ Res 1982;27:325-36.

8 Burrell R, Lantz RC, Hinton DE. Mediators of pulmonary injury induced by inhalation of endotoxin. Amer Rev Respir Dis 1988;137:100-5.

9 Webster RO, Larsen GL, Mitchell BC, Goins AJ, Henson PM. Absence of inflammatory lung injury in rabbits challenged intravascularly with complement-derived chemotactic factors. Am Rev Respir Dis 1982;125:335-40.

10 Henson PM, Larsen GL, Webster RO, Mitchell BC, Goins AJ, Henson JE. Pulmonary microvascular alterations and injury induced by complement fragments: synergistic effect of complement activation, neutrophil sequestration, and prostaglandins. Ann NY Acad Sci 1982;384:287-300.

11 Larsen GL, Webster RO, Worthen GS, Gumbay RS, Henson PM. Additive effect of intravascular complement-activation and brief episodes of hypoxia in producing increased permeability in the rabbit lung. J Clin Invest 1985;75:902-10.

12 Nerlich M, Flynn J, Demling RH. Effect of thermal injury on endotoxin-induced lung injury. Surgery 1983;93:289-96.

Accepted 19 March 1990

\section{Destruction of manuscripts}

From 1 July 1985 articles submitted for publication will not be returned. Authors whose papers are rejected will be advised of the decision and the manuscripts will be kept under security for three months to deal with any inquiries and then destroyed. 